Article

\title{
Hydrometallurgical Recovery of Cobalt(II) from Spent Industrial Catalysts
}

\author{
Zuzanna Wiecka ${ }^{1}$, Martyna Rzelewska-Piekut ${ }^{1}$, Ryszard Cierpiszewski ${ }^{2}$, Katarzyna Staszak ${ }^{1}[0$ \\ and Magdalena Regel-Rosocka ${ }^{1, *(D)}$ \\ 1 Institute of Chemical Technology and Engineering, Poznan University of Technology, ul. Berdychowo 4, \\ 60-965 Poznań, Poland; zuzanna.g.wiecka@doctorate.put.poznan.pl (Z.W.); \\ martyna.rzelewska-piekut@put.poznan.pl (M.R.-P.); katarzyna.staszak@put.poznan.pl (K.S.) \\ 2 Department of Commodity Science and Ecology of Industrial Products, Faculty of Commodity Science, \\ Poznań University of Economics and Business, Al. Niepodległości 10, 61-875 Poznań, Poland; \\ Ryszard.Cierpiszewski@ue.poznan.pl \\ * Correspondence: magdalena.regel-rosocka@put.poznan.pl
}

Received: 2 December 2019; Accepted: 30 December 2019; Published: 1 January 2020

check for updates

\begin{abstract}
The work presents studies on the application of hydrometallurgical recovery of cobalt(II) from solutions after leaching spent industrial catalysts used in process of hydrodesulfurization. A four-stage process was proposed, which consists of: leaching, precipitation of metal hydroxides accompanying $\mathrm{Co}(\mathrm{II})$, extraction of $\mathrm{Co}(\mathrm{II})$ with bis(2,4,4-trimethylpentyl)phosphinic acid and $\mathrm{Co}(\mathrm{II})$ stripping from the organic phase. The results indicate that by using the proposed method it is possible to leach $\mathrm{Co}(\mathrm{II})$ and $\mathrm{Mo}(\mathrm{VI})$ from spent catalyst, and remove main impurities such as $\mathrm{Al}(\mathrm{III}), \mathrm{Fe}(\mathrm{III})$ in hydroxide precipitation step and separate $\mathrm{Co}(\mathrm{II})$ from $\mathrm{Mo}(\mathrm{VI})$ by extraction and stripping.
\end{abstract}

Keywords: spent catalyst; cobalt recovery; hydrodesulfurization catalyst; leaching; hydrometallurgy; liquid-liquid extraction; Cyanex 272

\section{Introduction}

The search for new, alternative metal sources is not only driven by scientific curiosity but nowadays also an industrial necessity. The obligation is conditioned by economic and financial need, as well as, a conversion from the, so-called, linear economy to the world circular economy. Such metal sources include, among others electronic wastes (known as waste electrical and electronic equipment WEEE or e-waste, including waste printed circuit boards (WPCBs)), spent automotive catalysts, electroplating wastes, or a wide range of catalysts, especially from the chemical and petrochemical industry [1-4].

It should be noted that over $60 \%$ of all chemicals are produced using catalysts in $90 \%$ of all industrial chemical processes [5]. Wherein $80 \%$ of catalysts are in the solid form, less common are homogeneous and biocatalysts, about $17 \%$ and $3 \%$, respectively [6]. Due to the widespread use of catalysts, as well as their limited lifetime and the possibility of regeneration [7], the problem of their utilization is widely discussed in the literature [8-10]. Especially, that according to the United State Environmental Protection Agency (EPA) catalysts are classified as "hazardous waste as one posing a substantial or potential hazard to human health and the environment" [11]. Besides, many studies are carried out on the recovery of valuable elements from spent catalyst, especially the platinum-group metals (PGMs) [12], the rare-earth elements (REEs) [13], and the variety of transition metals [14]. Several methods are proposed and successfully used in academic and industrial practice. The conventional approaches used in metal reclamation as pyrometallurgy [15] and hydrometallurgy (leaching, ion exchange, extraction) [16-18], as well as new methods, include bioleaching [19]. As was mentioned above such methods are applied also in commercial solutions, i.e., the Dutch company 
Moxba-Metrex [20], the Germany company Nickelhütte Aue GmbH [21], or the Belgian company Sadaci N.V. [22], etc., described in detail in the work [23]. The selection of the right method depends on many factors [24]. Generally, the pyrometallurgical processes are appropriate for the treatment of high-grade ores, while hydrometallurgical processes for the treatment of low-grade or complex ores. It should be emphasized that in the case of high content of metals both methods could be used, although pyrometallurgy is more economic. At the same time, this method is unsuitable either for low content of metals in the material because a large amount of energy is required to melt associated gangues, or for complex ores due to difficulties in separation of the components. Moreover, there is no possibility to separate chemically similar metals in contrast to hydrometallurgy. Since catalysts are usually secondary ores containing small amounts of metals, most of the techniques proposed are based on hydrometallurgical processes [25,26]. Additionally, hydrometallurgy has some advantages such as low cost requirements, possible recovery of leachants and no air pollution, in contrast to emission of hazardous gases ( $\mathrm{SO}_{2}$, dioxins, furans) during pyrometallurgical processes. For sustainable development, bioleaching of metals is also recommended [27]. It seems to be promising due to its' environmental friendliness, and low cost and low energy requirements. However, the use of microorganisms, bacteria or fungi means that this process requires a longer time in comparison to the conventional chemical leaching, and strongly depends on atmospheric conditions.

Although the recovery of metals from spent catalysts has been known for many years, new recovery methods are still being sought, considering various industrial catalysts, as well as operating conditions. Therefore, taking into account the advantages and disadvantages of the available recovery methods, the work aims in the investigation of the possibility of the hydrometallurgical recovery of cobalt(II) from spent industrial hydrodesulfurization catalyst, with the optimal selection of leaching and extraction processes applied.

\section{Results and Discussion}

CoMo catalysts are prepared by successive impregnation steps of the alumina support with metal solutions. As a result of the impregnation, Co exists as a thin layer between the Mo layer and the $\mathrm{Al}$ support. Usually cobalt is deposited on alumina support first, and then molybdenum (in the oxidized form of $\mathrm{Mo}(\mathrm{VI})$ ) is impregnated on the Al-Co material [28]. Spent hydrodesulfurization (HDS) catalysts can be treated as a valuable source of cobalt. Thus, hydrometallurgical recovery of Co(II) from CoMo catalyst was proposed in this work in a four-step process shown in Figure 1.

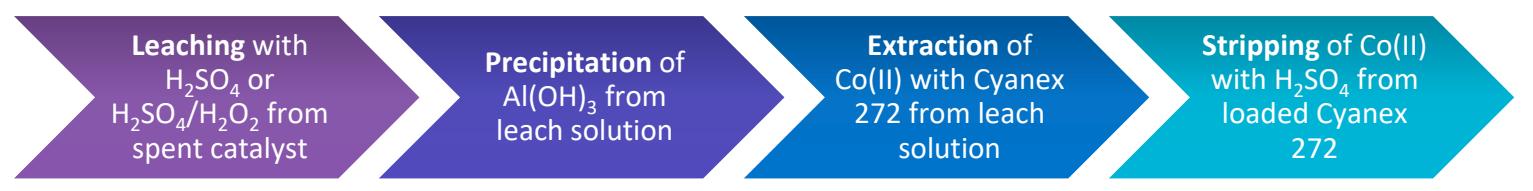

Figure 1. Four-step process for hydrometallurgical recovery of Co(II) from CoMo catalyst of hydrodesulfurization.

\subsection{Leaching of $\mathrm{Co}(I I)$}

The first step of spent catalyst treatment was leaching of metals from a ground CoMo catalyst with sulfuric acid solutions or mixtures of sulfuric acid and hydrogen peroxide. It should be emphasized that, although some authors recommend leaching from HDS catalysts with mixtures of mineral acids (e.g., $\mathrm{HNO}_{3} / \mathrm{H}_{2} \mathrm{SO}_{4} / \mathrm{HCl}$ [29] or $\mathrm{HNO}_{3} / \mathrm{H}_{2} \mathrm{SO}_{4}$ [30]), in this case sulfuric acid was chosen as a leaching agent to provide appropriate solution for the third step of the planned process, i.e., extraction with acidic extractant Cyanex 272. It should be noted that most data in the literature refer to sulfate solutions, while the application of Cyanex 272 in chloride and nitrate solutions is possible but less effective [31]. The results of leaching efficiency (LE), for different sulfuric acid concentrations, are shown in Figure 2. 


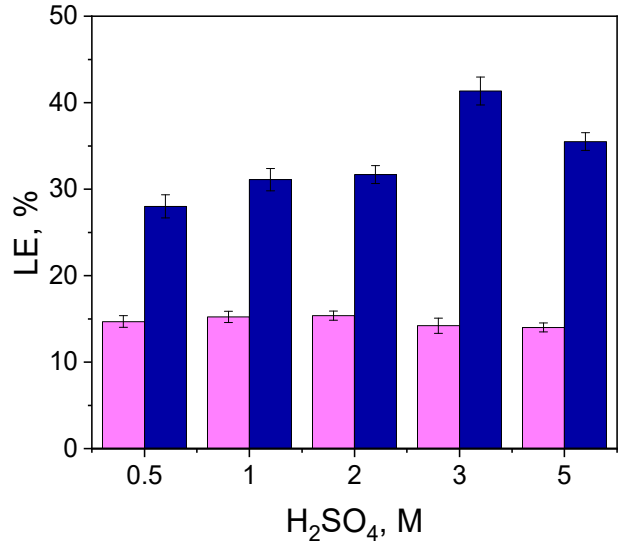

(a)

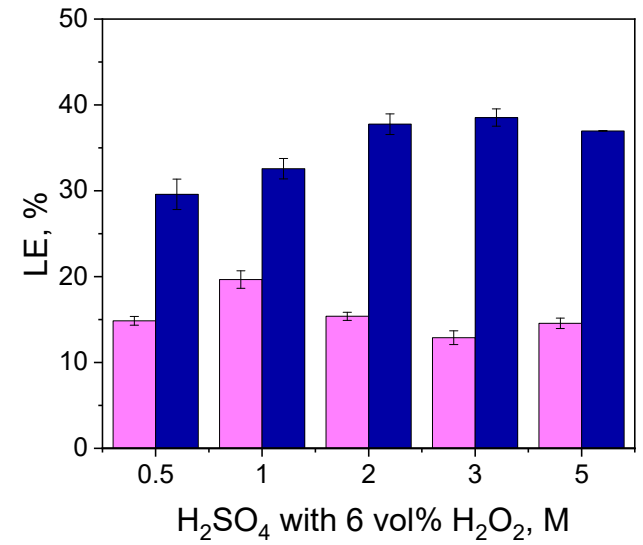

(b)

Figure 2. Efficiency of $\mathrm{Co}(\mathrm{II})(\square)$ and $\mathrm{Mo}(\mathrm{VI})(\mathbf{\square})$ leaching from spent industrial catalyst with (a) sulfuric acid solutions, (b) sulfuric acid solutions with addition of $6 \mathrm{vol} \%$ of $30 \% \mathrm{H}_{2} \mathrm{O}_{2}\left(50{ }^{\circ} \mathrm{C}, \mathrm{S} / \mathrm{L}=1 / 20 \mathrm{~g} / \mathrm{cm}^{3}\right.$, particle size of catalyst $<45 \mu \mathrm{m}$, stirring $300 \mathrm{rpm}$ ).

The leaching efficiency (LE) of cobalt(II) and molybdenum(VI) was calculated according to the following equation:

$$
\mathrm{LE}=\frac{m_{\text {leach }}}{m_{0}} \cdot 100 \%
$$

where $m_{0}, m_{\text {leach }}$ stand for mass of metal ions in the spent catalyst before leaching and in the leach solution after leaching, respectively. Initial mass of metal in the catalyst was estimated on the base of metal content $\left(u_{M}\right)$ according to XRF analysis $\left(u_{C o}=0.124, u_{M o}=0.359\right)$ and mass of the sample taken to leaching $\left(m_{\text {cat }}\right)$ as follows:

$$
m_{0}=m_{c a t} \cdot u_{M}
$$

The efficiency of $\mathrm{Co}$ (II) leaching with the solutions of sulfuric acid (in the studied range of concentrations) without and with the addition of $\mathrm{H}_{2} \mathrm{O}_{2}$ reached as maximum $20 \%$ (Figure 2). The leaching agents were more effective for $\mathrm{Mo}(\mathrm{VI})$ leading to the dissolution of $30-40 \%$ of this metal (Figure 2). An increase in acid concentration (between 0.5 and $5 \mathrm{M}$ ) did not affect significantly the amount of the leached $\mathrm{Co}(\mathrm{II})$, while it increased the amount of Mo(VI) leached.

Also, other researchers have indicated that direct leaching of the spent catalyst with sulfuric acid was not effective, whereas the combination of sulfuric and nitric acid significantly enhanced the recovery of $\mathrm{Mo}(\mathrm{VI})$ and $\mathrm{Co}(\mathrm{II})$ [30]. However, they reported that at $\mathrm{S} / \mathrm{L}=1 / 10,50{ }^{\circ} \mathrm{C}$ and $400 \mathrm{rpm}$ cobalt(II) was better extracted than $\mathrm{Mo}(\mathrm{VI})$, and the leaching efficiency with $1.5 \mathrm{M} \mathrm{H}_{2} \mathrm{SO}_{4}$ reached 55.3 and $19.3 \%$ after $4 \mathrm{~h}$ of reaction time. The mixture of $\mathrm{HNO}_{3} / \mathrm{H}_{2} \mathrm{SO}_{4}$ caused an increase in metal leaching up to almost $80 \%$ of $\mathrm{Mo}(\mathrm{VI})$ and more than $90 \%$ of $\mathrm{Co}(\mathrm{II})$ (after $5 \mathrm{~h}$ ). Furthermore, it was reported by other researchers [29] that the leaching efficiency of $\mathrm{Mo}(\mathrm{VI})$ and $\mathrm{Co}(\mathrm{II})$ with mixtures of $\mathrm{HNO}_{3} / \mathrm{H}_{2} \mathrm{SO}_{4} / \mathrm{HCl}$ and $\mathrm{HNO}_{3} / \mathrm{H}_{2} \mathrm{SO}_{4}$ acids are 86 and $87 \%$ for $\mathrm{Mo}(\mathrm{VI})$ and 91 and $93 \%$ for $\mathrm{Co}(\mathrm{II})$, respectively.

Although higher efficiency of the leaching could be obtained with the addition of $\mathrm{HNO}_{3}$, in this work only sulfuric acid was chosen as the leaching agent because of further steps of $\mathrm{Co}$ (II) recovery, i.e., extraction and stripping that provide purified Co(II) electrolyte which can be used for electrowinning of metallic cobalt.

The reactions considered during leaching of these metals are as follows [28,32]:

$$
\begin{gathered}
\mathrm{CoO}+\mathrm{H}_{2} \mathrm{SO}_{4}=\mathrm{CoSO}_{4}+\mathrm{H}_{2} \mathrm{O} \\
\mathrm{MoO}_{3}+\mathrm{H}_{2} \mathrm{SO}_{4}=\mathrm{MoO}_{2} \mathrm{SO}_{4}+\mathrm{H}_{2} \mathrm{O} \\
\mathrm{Al}_{2} \mathrm{O}_{3}+3 \mathrm{H}_{2} \mathrm{SO}_{4}=\mathrm{Al}_{2}\left(\mathrm{SO}_{4}\right)_{3}+3 \mathrm{H}_{2} \mathrm{O}
\end{gathered}
$$


The addition of an oxidant, i.e., $\mathrm{H}_{2} \mathrm{O}_{2}$, did not cause a significant increase in the leaching efficiency. Either in the presence of hydrogen peroxide or without it, $\mathrm{Co}(\mathrm{II})$ concentration in the leach solutions and leaching efficiency of $\mathrm{Co}$ (II) were comparable. In the case of $\mathrm{Mo}(\mathrm{VI})$ leaching, the addition of $\mathrm{H}_{2} \mathrm{O}_{2}$ increased efficiency by 1.5 to 6 percentage points. As no significant effect of the $\mathrm{H}_{2} \mathrm{O}_{2}$ addition was observed, investigation of the temperature and time influence on metal leaching was carried out with sulfuric acid alone. Moreover, the use of $\mathrm{H}_{2} \mathrm{O}_{2}$ is disadvantageous due to the high price of the oxidant.

To achieve efficient $\mathrm{Co}$ (II) leaching, the operation was carried out in various temperatures (Figure 3 ). A slight increase in ion content of both metals (Co(II) and Mo(VI)) in the solution was observed with increasing temperature of leaching within the range from 23 to $95 \pm 2{ }^{\circ} \mathrm{C}$.

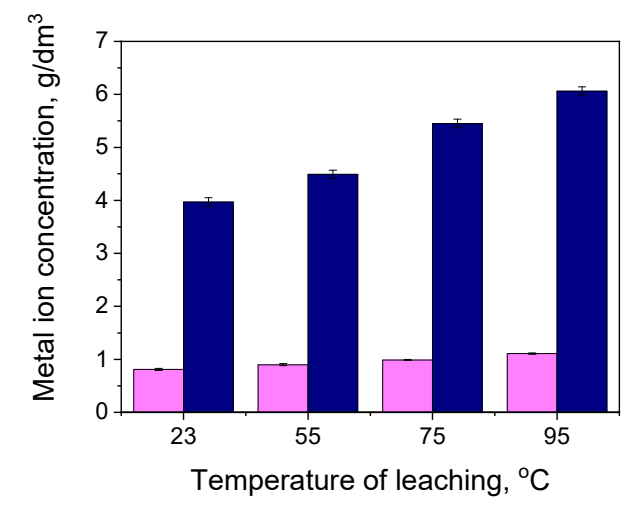

Figure 3. Dependence of $\mathrm{Co}(\mathrm{II})(\square)$ and $\mathrm{Mo}(\mathrm{VI})(\square)$ concentration in the leach solutions on temperature of leaching for $3 \mathrm{~h}$ with $0.5 \mathrm{M} \mathrm{H}_{2} \mathrm{SO}_{4}$ at $\mathrm{S} / \mathrm{L}=1 / 20 \mathrm{~g} / \mathrm{cm}^{3}$.

The change in concentration of various metals in the leaching solution during $3 \mathrm{~h}$ of leaching

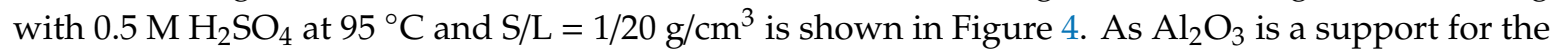
active metals, and the content of aluminium in the leached material is the highest of all the metals, the concentration of the dissolved $\mathrm{Al}(\mathrm{III})$ is also the highest (almost $10 \mathrm{~g} / \mathrm{dm}^{3}$ ). However, concerning the initial content (Table 7), the loss of aluminium from the solid material of the catalyst is not as large as of cobalt, iron or copper (Table 1). Also, low efficiency of $\mathrm{Al}(\mathrm{III})$ leaching (about 10\%) in contrast to $70-86 \%$ for $\mathrm{Ni}$ from spent catalysts $\left(\mathrm{NiO} / \mathrm{Al}_{2} \mathrm{O}_{3}\right)$ was obtained by Miazga and Mulak [33]. Moreover, Hamza et al. [28] reported poor leaching of $\mathrm{Al}(\mathrm{III})$ (about $5 \%$ ) and they attributed it to worse accessibility of the catalyst support to the leaching agent. However, they mainly leached raw, not ground, material, while in our case aluminium is well-accessed because the catalyst is in the form of fine powder (particle size below $45 \mu \mathrm{m}$ ). Thus, not only a thin layer of cobalt and molybdenum but also aluminium are dissolved by the leaching agent.

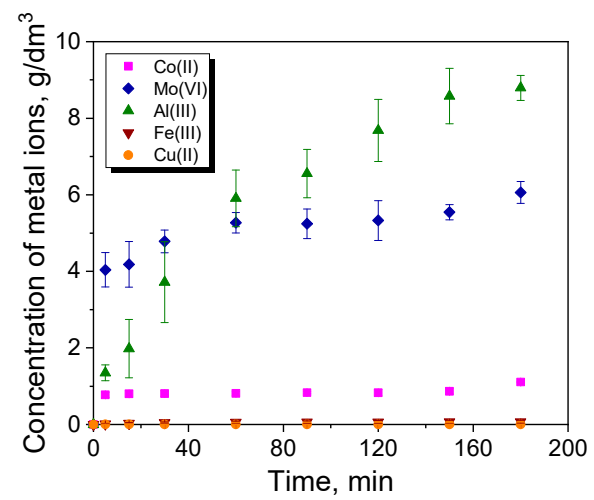

Figure 4. Change in concentration of metal ions in the leach solution during leaching for $3 \mathrm{~h}$ with $0.5 \mathrm{M}$ $\mathrm{H}_{2} \mathrm{SO}_{4}$ at $95^{\circ} \mathrm{C}, \mathrm{S} / \mathrm{L}=1 / 20 \mathrm{~g} / \mathrm{cm}^{3}$. 
Table 1. An exemplary composition of the spent catalyst after leaching with $1 \mathrm{M} \mathrm{H}_{2} \mathrm{SO}_{4}$ at $55^{\circ} \mathrm{C}, \mathrm{S} / \mathrm{L}=$ $1 / 20 \mathrm{~g} / \mathrm{cm}^{3}$.

\begin{tabular}{ccc}
\hline Chemical Element & Percentage Composition after Leaching, \% & Loss in Element Content after Leaching, \% \\
\hline $\mathrm{Al}$ & 43.6 & 19.0 \\
$\mathrm{Mo}$ & 35.3 & 14.9 \\
$\mathrm{Co}$ & 4.54 & 68.3 \\
$\mathrm{Fe}$ & 0.20 & 76.2 \\
$\mathrm{Cu}$ & 0.02 & 79.4 \\
\hline
\end{tabular}

The results of XRF analysis of the samples after leaching with sulfuric acid confirmed depletion of more than $60 \%$ of cobalt, almost $60 \%$ of copper and $80 \%$ of iron. However, the concentration of Cu(II) or Fe ions in the leaching solution is low (Figure 4) because the initial content of these metals in the catalyst is small (Table 7).

\subsection{Precipitation of Impurities}

After leaching the solid residue was separated from the leach solution. The aqueous phase containing ions of various metals (i.e., $\mathrm{Al}(\mathrm{III}), \mathrm{Fe}(\mathrm{III}), \mathrm{Cu}(\mathrm{II}), \mathrm{Ni}(\mathrm{II}), \mathrm{Co}(\mathrm{II}), \mathrm{Mo}(\mathrm{VI})$ ) was treated with $\mathrm{NaOH}$ solution to precipitate hydroxides of the metals accompanying $\mathrm{Co}(\mathrm{II})$, according to the reaction:

$$
A l^{3+}+3 \mathrm{NaOH}=\mathrm{Al}(\mathrm{OH})_{3, \text { solid }}+3 \mathrm{Na}^{+}
$$

Metal content in the deposits precipitated from various leach solutions is presented in Table 2.

Table 2. Metal content in the selected deposits after precipitation with $30 \% \mathrm{NaOH}$ solution.

\begin{tabular}{cccccc}
\hline \multirow{2}{*}{ Leaching Solutions } & \multicolumn{5}{c}{ Contents in the Sediment after Precipitation, mg } \\
\cline { 2 - 6 } & $\mathbf{C o ( I I )}$ & $\mathbf{M o}(\mathrm{VI})$ & $\mathbf{N i}(\mathrm{II})$ & $\mathrm{Cu}(\mathrm{II})$ & $\mathrm{Fe}(\mathrm{III})$ \\
\hline $1 \mathrm{M} \mathrm{H}_{2} \mathrm{SO}_{4}$ & 0.768 & 0.160 & 0.004 & 0.019 & 0.223 \\
$1 \mathrm{M} \mathrm{H}_{2} \mathrm{SO}_{4}+\mathrm{H}_{2} \mathrm{O}_{2}$ & 0.857 & 0.180 & 0.004 & 0.016 & 0.106 \\
$5 \mathrm{M} \mathrm{H}_{2} \mathrm{SO}_{4}$ & 0.182 & 0.620 & 0.000 & 0.002 & 0.013 \\
$5 \mathrm{M} \mathrm{H}_{2} \mathrm{SO}_{4}+\mathrm{H}_{2} \mathrm{O}_{2}$ & 0.172 & 1.015 & 0.000 & 0.004 & 0.028 \\
\hline
\end{tabular}

Along with $\mathrm{Mo}(\mathrm{VI})$ and $\mathrm{Fe}(\mathrm{III})$, also $\mathrm{Co}(\mathrm{II})$ is precipitated which is disadvantageous for $\mathrm{Co}(\mathrm{II})$ recovery due to loss of this metal. The main aim of the precipitation step is the removal of $\mathrm{Al}(\mathrm{III})$ before the extraction of $\mathrm{Co}(\mathrm{II})$. The smallest loss of $\mathrm{Co}(\mathrm{II})$ in the deposit $(0.100 \mathrm{mg})$ is noted from the leachate of $0.5 \mathrm{M} \mathrm{H}_{2} \mathrm{SO}_{4}$, probably because the final $\mathrm{pH}$ of precipitation was equal to 3.5 , while $\mathrm{Co}$ (II) precipitation increases with increasing $\mathrm{pH}$. As Huang et al. [34] indicated, major cobalt precipitation occurred within a $\mathrm{pH}$ range of 5-7. However, the $\mathrm{pH}$ increase from 4 to 5 enhances substantially also molybdenum(VI) precipitation from the solutions [34]. Consequently, various ratios of Co(II) and $\mathrm{Mo}(\mathrm{VI})$ in the precipitate can result from changes in composition of the deposit, for example, from cobalt hydroxide $\left(\mathrm{Co}(\mathrm{OH})_{2}\right)$, through cobalt molybdenum oxide hydrate $\left(\mathrm{CoMoO}_{6} \cdot 0.9 \mathrm{H}_{2} \mathrm{O}\right)$ to sodium cobalt molybdenum oxide $\left(\mathrm{NaCo}_{2.31}\left(\mathrm{MoO}_{4}\right)_{3}\right)$ [34]. Thus, as $\mathrm{Co}(\mathrm{II})$ loss was the lowest, $0.5 \mathrm{M}$ $\mathrm{H}_{2} \mathrm{SO}_{4}$ was selected as the most appropriate for the four-step process. Additionally, the use of low concentrated acid is advantageous from the environmental protection and economic point of view. An important aspect of precipitation is $\mathrm{Al}(\mathrm{III})$ removal from the leachate because at $\mathrm{pH} 5$ (extraction $\mathrm{pH}) \mathrm{Al}(\mathrm{III})$ would start to precipitate and disturb $\mathrm{Co}(\mathrm{II})$ extraction. Content of $\mathrm{Al}(\mathrm{III})$ in the solutions before and after precipitation with $30 \% \mathrm{NaOH}$ is shown in Table 3. 
Table 3. $\mathrm{Al}(\mathrm{III})$ content in solution after leaching with $0.5 \mathrm{M} \mathrm{H}_{2} \mathrm{SO}_{4}$ and after precipitation with $30 \% \mathrm{NaOH}$.

\begin{tabular}{ccc}
\hline \multirow{2}{*}{ Temperature of Leaching, ${ }^{\circ} \mathbf{C}$} & \multicolumn{2}{c}{ Al(III) Content in Solution, mg } \\
\cline { 2 - 3 } & After Leaching & After Precipitation \\
\hline 23 & 34.4 & 0.8 \\
55 & 77.3 & 0.6 \\
75 & 212.0 & 1.2 \\
95 & 296.3 & 2.1 \\
\hline
\end{tabular}

As shown in Table 3, precipitation with 30\% $\mathrm{NaOH}$ leads to effective removal of $\mathrm{Al}(\mathrm{III})$ ions from the solution. However, it is not a selective operation because hydroxides of other elements are also precipitated. To estimate the loss of Co(II) during the precipitation, the efficiency of precipitation (P) was calculated as follows:

$$
\mathrm{P}=\frac{m_{1}}{m_{2}} \cdot 100 \%
$$

where: $m_{1}$-mass of the precipitated $\mathrm{Co}(\mathrm{II}), m_{2}$-mass of $\mathrm{Co}$ (II) before the precipitation. The efficiency of $\mathrm{Co}$ (II) precipitation depending on the temperature in which the previous step, i.e., leaching, was carried out, is shown in Figure 5.

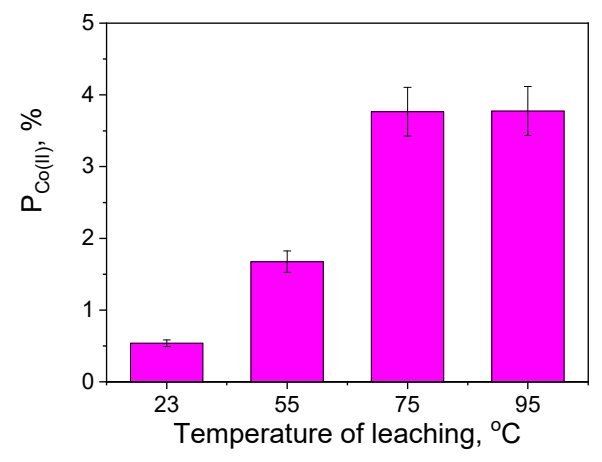

Figure 5. The efficiency of $\mathrm{Co}(\mathrm{II})$ precipitation from solutions after leaching with $0.5 \mathrm{M} \mathrm{H}_{2} \mathrm{SO}_{4}$ at various temperatures.

The efficiency of $\mathrm{Co}$ (II) precipitation was calculated for the mass of the whole precipitate obtained during the precipitation. The highest $\mathrm{Co}$ (II) losses (about $4 \%$ ) were found in the samples after leaching at 75 and $95^{\circ} \mathrm{C}$ (Figure 5). In the samples after leaching at low temperatures $\left(23\right.$ and $\left.55^{\circ} \mathrm{C}\right)$, the amount of precipitated $\mathrm{Co}(\mathrm{II})$ is low and does not exceed $2 \%$. Additional XRF analysis (the results not presented in this work) showed that almost $60 \%$ of the mass of the precipitate is sulfur, which probably derives from sulfates from the leaching solution, and confirms that $\mathrm{Co}(\mathrm{II}), \mathrm{Mo}(\mathrm{VI})$, and $\mathrm{Al}(\mathrm{III})$ are deposited not only as hydroxides (Equation (6)) but also as mixed compounds [34,35], e.g., $\mathrm{Co}\left(\mathrm{SO}_{4}\right)_{\mathrm{i}}(\mathrm{OH})_{\mathrm{j}} \cdot \mathrm{kH}_{2} \mathrm{O}$, $\mathrm{MoO}_{2} \mathrm{SO}_{4}, 2 \mathrm{Al}_{2} \mathrm{O}_{3} \cdot \mathrm{SO}_{3} \cdot 11 \mathrm{H}_{2} \mathrm{O}$, respectively. The XRF analysis confirmed that some amount of $\mathrm{Co}(\mathrm{II})$ is co-precipitated which causes loss of $\mathrm{Co}$ (II) from the solution forwarded to the next step-extraction.

\subsection{Extraction of $\mathrm{Co}(\mathrm{II})$}

Various organic compounds were reported as extractants for $\mathrm{Co}(\mathrm{II})$ or $\mathrm{Mo}(\mathrm{VI})$ separation from leachates. For example, basic tertiary amine (Alamine 304) was proposed to extract $\mathrm{Mo}(\mathrm{VI})$ from $\mathrm{H}_{2} \mathrm{SO}_{4}$ at $\mathrm{pH} 1.8$ [32]. Also, two-step extraction with neutral tributylphosphate (TBP) or basic tris-2-ethylhexylamine (TEHA) was shown to be effective for removal of $\mathrm{Mo}(\mathrm{VI})$ or $\mathrm{Co}(\mathrm{II})$, respectively, from $\mathrm{HCl}$ [36]. Another combination of extractants was proposed, i.e., trioctylphospine oxide (TOPO) and tertiary amine Alamine 308, to extract $\mathrm{Mo}(\mathrm{VI})$ and $\mathrm{Co}(\mathrm{II})$, respectively, from $3 \mathrm{M} \mathrm{HCl}$ [37]. However, in this work, bis(2,4,4-trimethylpentyl)phosphinic acid (Cyanex 272) was chosen to separate Co(II) 
from the leachate and next to transfer it to sulfate stripping solution. On the one hand, extraction with Cyanex 272 makes possible generate Co(II) electrolyte for further electrowinning, on the other hand, only one-step extraction reduces the amount of the organics used in the process. Our previous works have shown that Cyanex 272 or its sodium salt can selectively extract $\mathrm{Co}$ (II) in the presence of $\mathrm{Ni}(\mathrm{II})[38,39]$. An effective $\mathrm{Co}(\mathrm{II})$ extraction from solution containing a hundredfold excess of $\mathrm{Ni}(\mathrm{II})$ has been confirmed also by other authors [40].

Thus, after removal of $\mathrm{Al}(\mathrm{III})$ and $\mathrm{Mo}(\mathrm{VI})$ from the aqueous phase, liquid-liquid extraction with $0.4 \mathrm{M}$ Cyanex 272 to recover $\mathrm{Co}(\mathrm{II})$ and separate it from ions of other metals. Percentage extraction of Co(II) was calculated as follows:

$$
\mathrm{E}=\frac{m_{\text {org }}}{m_{\text {aq }, 0}} \cdot 100 \%
$$

where $m_{a q, 0}, m_{\text {org }}$ stand for metal mass in the aqueous phase before extraction and in the organic phase after extraction, respectively. Results of Co(II) extraction are compared with the conditions (acid concentration) of the leaching stage, and shown in Figure 6.

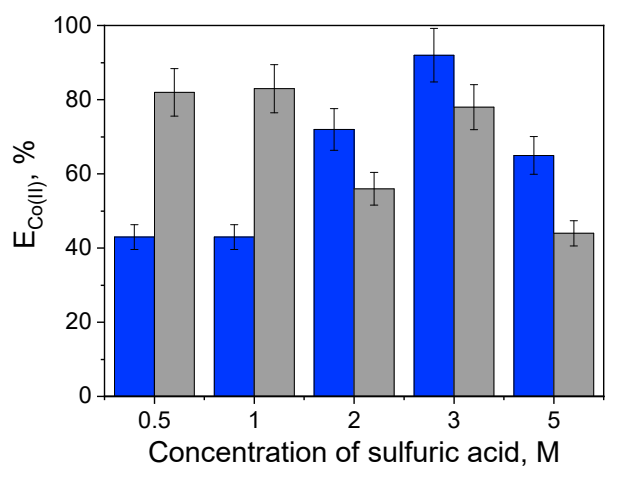

(a)

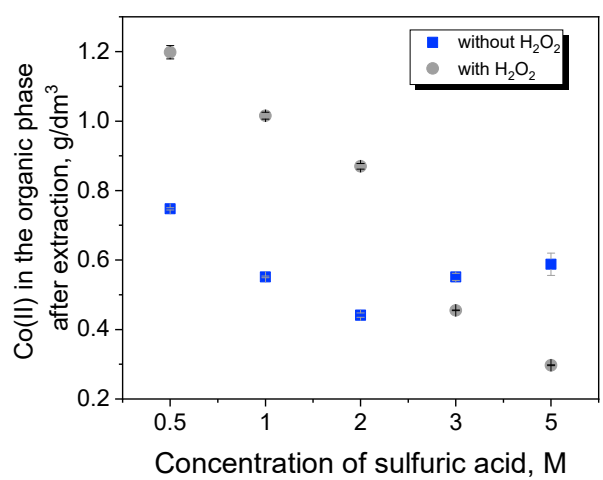

(b)

Figure 6. Dependence of (a) percentage extraction of $\mathrm{Co}(\mathrm{II})$, (b) concentration of $\mathrm{Co}$ (II) in the organic phase after extraction from solutions after leaching with ( $\square$ ) sulfuric acid or ( $\square$ ) sulfuric acid with $\mathrm{H}_{2} \mathrm{O}_{2}$ addition.

It was shown in our previous work that the best conditions for $\mathrm{Co}(\mathrm{II})$ extraction are at $\mathrm{pH}$ 5.2-5.5 [38]. Also, manufacturer of Cyanex 272 reports that at $\mathrm{pH} 5.5$ maximum extraction of cobalt(II) from sulfate solution can be obtained, while ions of other metals present in our system extract efficiently at different $\mathrm{pH}$ values ( $\mathrm{Al}$ at 2.8, $\mathrm{Fe} \mathrm{pH}$ 2.1, $\mathrm{Cu} \mathrm{pH} \mathrm{4,} \mathrm{Ni} \mathrm{pH} \mathrm{7.5)} \mathrm{[41].} \mathrm{Moreover,} \mathrm{it} \mathrm{was} \mathrm{important} \mathrm{to}$ remove $\mathrm{Mo}(\mathrm{VI})$ and $\mathrm{Al}(\mathrm{III})$ before $\mathrm{Co}(\mathrm{II})$ extraction because they start to precipitate at $\mathrm{pH} 3$ and the formation of the deposit becomes substantial at $\mathrm{pH} 5$ [28,34]. The highest $\mathrm{Co}$ (II) extraction efficiency is noted when leaching was carried out with $3 \mathrm{M} \mathrm{H}_{2} \mathrm{SO}_{4}$, while for leach solutions with the addition of $6 \mathrm{vol} \%$ of $30 \% \mathrm{H}_{2} \mathrm{O}_{2}$ percentage extraction of $\mathrm{Co}$ (II) exceeded $80 \%$ when $0.5,1$ and $3 \mathrm{M} \mathrm{H}_{2} \mathrm{SO}_{4}$ solutions were used. However, it must be emphasized that $\mathrm{Co}(\mathrm{II})$ concentrations in the organic phase after extraction are the highest when $0.5 \mathrm{M} \mathrm{H}_{2} \mathrm{SO}_{4}$ solution, either with $\mathrm{H}_{2} \mathrm{O}_{2}$ or without it, was applied (Figure 6b).

\subsection{Stripping of $\mathrm{Co}(I I)$}

After selective extraction of $\mathrm{Co}(\mathrm{II})$ to the organic phase, an effective stripping of $\mathrm{Co}$ (II) from the loaded Cyanex 272 to $1 \mathrm{M}$ sulfuric acid solution was accomplished to form sulfate electrolyte solution. The final concentrations of $\mathrm{Co}(\mathrm{II})$ and $\mathrm{Mo}(\mathrm{VI})$ in the stripping aqueous phases in the selected experiments are shown in Table 4. 
Table 4. $\mathrm{Co}(\mathrm{II})$ and $\mathrm{Mo}(\mathrm{VI})$ concentrations in the stripping phase (after the forth step of leaching-precipitation-extraction-stripping process) for various conditions of the first step-leaching.

\begin{tabular}{|c|c|c|c|c|}
\hline Leaching Conditions & $\begin{array}{l}\text { Temperature of } \\
\text { Leaching, }{ }^{\circ} \mathrm{C}\end{array}$ & $\begin{array}{l}\text { Final } \mathrm{pH} \text { during } \\
\text { Precipitation }\end{array}$ & $\begin{array}{l}\text { Concentration of } \\
\mathrm{Mo}(\mathrm{VI}), \mathrm{g} / \mathrm{dm}^{3}\end{array}$ & $\begin{array}{c}\text { Concentration of } \\
\text { Co(II), } \mathrm{g} / \mathrm{dm}^{3}\end{array}$ \\
\hline $2 \mathrm{M} \mathrm{H}_{2} \mathrm{SO}_{4}+\mathrm{H}_{2} \mathrm{O}_{2}$ & 55 & 3.5 & 0.00 & 0.77 \\
\hline \multirow{2}{*}{$1 \mathrm{M} \mathrm{H}_{2} \mathrm{SO}_{4}$} & \multirow{2}{*}{55} & 4 & 0.00 & 1.56 \\
\hline & & 5 & 0.00 & 2.23 \\
\hline $1 \mathrm{M} \mathrm{H}_{2} \mathrm{SO}_{4}+\mathrm{H}_{2} \mathrm{O}_{2}$ & 55 & 5 & 0.00 & 1.44 \\
\hline \multirow[t]{2}{*}{$0.5 \mathrm{M} \mathrm{H}_{2} \mathrm{SO}_{4}$} & 55 & 3.5 & 0.00 & 2.69 \\
\hline & 23 & 5 & 0.07 & 1.93 \\
\hline \multirow{3}{*}{$0.5 \mathrm{M} \mathrm{H}_{2} \mathrm{SO}_{4}$} & 55 & 5 & 0.05 & 2.22 \\
\hline & 75 & 5 & 0.07 & 2.53 \\
\hline & 95 & 5 & 0.34 & 3.63 \\
\hline $0.5 \mathrm{M} \mathrm{H}_{2} \mathrm{SO}_{4}+\mathrm{H}_{2} \mathrm{O}_{2}$ & 55 & 3.5 & 0.00 & 1.25 \\
\hline
\end{tabular}

In almost all solutions after stripping no $\mathrm{Mo}(\mathrm{VI})$ was detected. Very low concentration of $\mathrm{Mo}(\mathrm{VI})$ was noted after the four-stage process in which the temperature was changed during the first step, i.e., leaching. Based on the results presented in Table 4 it can be concluded that in most cases Co(II) was efficiently separated from $\mathrm{Mo}(\mathrm{VI})$ by extraction and stripping.

To summarize the process, mass of $\mathrm{Co}(\mathrm{II})$ and $\mathrm{Mo}(\mathrm{VI})$ in the solutions after leaching and in the solutions after stripping is shown in Table 5. The yield (Y) of the four-stage Co(II) separation process was calculated as follows:

$$
\mathrm{Y}=\frac{m_{\text {strip }}}{m_{\text {leach }}} \cdot 100 \%
$$

where: $m_{\text {leach }}$-mass of $\mathrm{Co}(\mathrm{II})$ or $\mathrm{Mo}(\mathrm{VI})$ after leaching, $m_{\text {strip }}$-mass of $\mathrm{Co}(\mathrm{II})$ or $\mathrm{Mo}(\mathrm{VI})$ after stripping.

Table 5. Recovery yield of $\mathrm{Co}(\mathrm{II})$ and $\mathrm{Mo}(\mathrm{VI})$ in the four-step process (leaching-precipitation-extraction-stripping).

\begin{tabular}{|c|c|c|c|c|c|c|}
\hline \multirow{2}{*}{$\begin{array}{c}\text { Temperature of } \\
\text { Leaching with } 0.5 \mathrm{M} \\
\mathrm{H}_{2} \mathrm{SO}_{4},{ }^{\circ} \mathrm{C}\end{array}$} & \multicolumn{2}{|c|}{$\begin{array}{l}\text { Concentration in the } \\
\text { Leach Solution, } \mathrm{g} / \mathrm{dm}^{3}\end{array}$} & \multicolumn{2}{|c|}{$\begin{array}{l}\text { Concentration in the } \\
\text { Stripping Solution, } \mathrm{g} / \mathrm{dm}^{3}\end{array}$} & \multicolumn{2}{|c|}{$Y, \%$} \\
\hline & Co(II) & Mo(VI) & Co(II) & Mo(VI) & Co(II) & Mo(VI) \\
\hline 23 & 0.81 & 3.97 & 1.93 & 0.07 & 16.5 & 0.08 \\
\hline 55 & 0.90 & 4.49 & 2.22 & 0.05 & 18.6 & 0.07 \\
\hline 75 & 0.99 & 5.45 & 2.53 & 0.07 & 19.8 & 0.12 \\
\hline 95 & 1.11 & 6.06 & 3.63 & 0.34 & 18.8 & 0.33 \\
\hline
\end{tabular}

Generally, the efficiency of Co(II) separation from solution after leaching did not exceed $20 \%$. The efficiency of $\mathrm{Mo}(\mathrm{VI})$ stripping did not exceed $1 \%$, thus, it was proven that $\mathrm{Co}(\mathrm{II})$ can be effectively separated from $\mathrm{Mo}(\mathrm{VI})$. However, further research should be carried out to increase the total yield of $\mathrm{Co}$ (II) recovery. As $\mathrm{Al}(\mathrm{III})$ is leached in a great amount from the catalyst, also the content of $\mathrm{Al}(\mathrm{III})$ in various solutions of the four-step process is shown in Table 6. 
Table 6. $\mathrm{Al}(\mathrm{III})$ content in four-step process: leaching-precipitation-extraction-stripping (leaching solution: $0.5 \mathrm{M} \mathrm{H}_{2} \mathrm{SO}_{4}$ at $95^{\circ} \mathrm{C}$ ).

\begin{tabular}{|c|c|c|c|c|c|}
\hline \multicolumn{6}{|c|}{$\mathrm{Al}(\mathrm{III})$ Content in Solution, $\mathrm{mg}$} \\
\hline \multicolumn{3}{|c|}{ Leaching, min } & \multirow{2}{*}{ After Precipitation } & \multirow{2}{*}{$\begin{array}{l}\text { Raffinate after } \\
\text { Extraction }\end{array}$} & \multirow{2}{*}{$\begin{array}{l}\text { Stripping } \\
\text { Solution }\end{array}$} \\
\hline 5 & 90 & 180 & & & \\
\hline 40.1 & 234.8 & 296.3 & 2.1 & 0.6 & 0.5 \\
\hline \multicolumn{6}{|c|}{$\mathrm{Al}(\mathrm{III})$ Concentration in Solution, $\mathrm{g} / \mathrm{dm}^{3}$} \\
\hline 1.33 & 7.82 & 9.87 & 0.12 & 0.05 & 0.28 \\
\hline
\end{tabular}

The amount of $\mathrm{Al}(\mathrm{III})$ in the stripping solution is comparable with $\mathrm{Mo}(\mathrm{VI})$ concentration and tenfold lower than $\mathrm{Co}(\mathrm{II})$ concentration. It means that cobalt(II) sulfate solution obtained after four steps of the process contains significantly less accompanying metal ions compared to the leaching solution. Finally, Co(II) recovery from spent industrial CoMo catalyst was carried out in six parallel leaching-precipitation-extraction-stripping processes. The results are shown in Figure 7 as concentrations of $\mathrm{Co}(\mathrm{II}), \mathrm{Mo}(\mathrm{VI})$ and $\mathrm{Al}(\mathrm{III})$ (in the aqueous solutions) after the consecutive steps of the process.

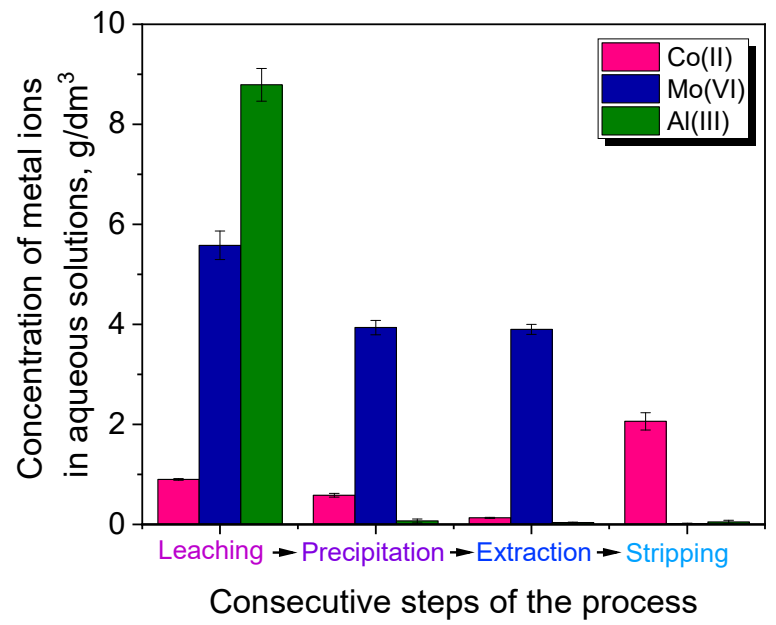

Figure 7. Flow of $\mathrm{Co}(\mathrm{II})(\square), \mathrm{Mo}(\mathrm{VI})(\square)$ and $\mathrm{Al}(\mathrm{III})(\square)$ in consecutive steps of the proposed process.

Compared to other processes developed to recover metals from spent catalysts [28,36,42], the advantage of our process lies in the fact that (1) the final solution contains cobalt(II) sulfate and is enriched in $\mathrm{Co}$ (II) related to the leaching solution, (2) separation of $\mathrm{Mo}$ (VI) is carried out in one extraction step, not two-step as proposed by others [36,37].

\section{Materials and Methods}

Sample of spent industrial CoMo catalyst was provided by a Polish waste treating company. The percentage content of elements determined by XRF analysis is presented in Table 7. Acidic extractant, i.e., bis(2,4,4-trimethylpentyl)phosphinic acid (Cyanex 272) supplied by Cytec Industries Inc. (Woodland Park, New Jersey, USA Solvay Group was used as an extractant $(0.4 \mathrm{M})$ and was dissolved in Exxsol D80 (ExxonMobil Chemical, Irving, Texas, USA) with the addition of modifier (i.e., $5 \mathrm{vol} \%$ decanol). The organic phase was regenerated after the previous extraction with sulfuric acid and scrubbed with water, and recycled to extraction. 
Table 7. Percentage content of elements in spent industrial CoMo catalyst.

\begin{tabular}{ccccccccc}
\hline Element & Al & Si & P & S & Cl & K & Ca & Mn \\
\hline Content, \% & 46.6 & 0.58 & 1.24 & 0.83 & 0.94 & 0.05 & 0.32 & 0.01 \\
\hline Element & Fe & Co & Cu & As & Se & Mo & Pb & - \\
\hline Content, $\%$ & 0.84 & 12.4 & 0.06 & 0.12 & 0.05 & 35.9 & 0.01 & - \\
\hline
\end{tabular}

The solution of $30 \%$ sodium hydroxide (Avantor, Gliwice, Poland) was used to precipitate metal hydroxides from the solution after leaching, and then to adjust $\mathrm{pH}$ during extraction with Cyanex 272. Sulfuric acid (Avantor, Gliwice, Poland) in the range from 0.5 to $5 \mathrm{M}$ was used as a leaching agent, in some cases, the addition of $30 \% \mathrm{H}_{2} \mathrm{O}_{2}$ (Avantor, Gliwice, Poland) was applied. Sulfuric acid also was employed as a stripping phase $(1 \mathrm{M})$ in all the cases, as it is the most convenient electrolyte for further electrowinning of metallic cobalt.

\subsection{Leaching Procedure}

The spent catalyst was ground, then sieved and a fraction of particle size below $45 \mu \mathrm{m}$ was separated. $1.5 \mathrm{~g}$ of the ground catalyst was placed in a reactor, and $30 \mathrm{~cm}^{3} \mathrm{of}_{2} \mathrm{SO}_{4}$ or $25 \mathrm{~cm}^{3}$ of $\mathrm{H}_{2} \mathrm{SO}_{4}$ with the addition of $5 \mathrm{~cm}^{3}$ of $\mathrm{H}_{2} \mathrm{O}_{2}$ was added. The solid to liquid (S/L) ratio was kept equal to $1 / 20 \mathrm{~g} / \mathrm{cm}^{3}$. The mixture of catalyst and the leaching agent was heated and mixed at $300 \mathrm{rpm}$, and the leaching was carried out in the range of temperature between 23 and $95 \pm 2{ }^{\circ} \mathrm{C}$. Leaching was investigated for $3 \mathrm{~h}$ and $1 \mathrm{~cm}^{3}$ sample was taken after 5, 15, 30, 60, 90, 120, 150, $180 \mathrm{~min}$ from the beginning of the leaching.

\subsection{Precipitation Procedure}

Precipitation of hydroxide deposit was carried out by slow addition of $30 \% \mathrm{NaOH}$ to the leach solution up to $\mathrm{pH} 5$. The precipitation was separated by centrifugation, and the liquid phase was taken to the next step, i.e., liquid-liquid extraction.

\subsection{Extraction-Stripping Procedure}

Extraction from model solutions was carried out in a typical batch way: aqueous feeds containing metal ions were mechanically shaken with the organic phase $0.4 \mathrm{M}$ Cyanex 272 (volume ratio w/o = 2) for $15 \mathrm{~min}$ at $23 \pm 2{ }^{\circ} \mathrm{C}$ in glass separation funnels, and then allowed to stand for phase separation. The $\mathrm{pH}$ of the aqueous phase was controlled by the addition of drops of $30 \% \mathrm{NaOH}$ solution and kept equal to 5-5.2. Stripping of metal ions from the organic phases loaded was carried out for 5 min with $1 \mathrm{M} \mathrm{H}_{2} \mathrm{SO}_{4}$ at o/w $=3$.

Atomic absorption spectroscopy (Contraa300, Analytik Jena, Jena, Germany) was applied to determine $\mathrm{Co}(\mathrm{II}), \mathrm{Cu}(\mathrm{II}), \mathrm{Fe}$ ions, $\mathrm{Ni}(\mathrm{II})$ concentrations in the aqueous solutions, microwave plasma-atomic emission spectroscopy (4210 MP AES, Agilent, Santa Clara, California, USA) was applied for $\mathrm{Al}(\mathrm{III})$, and $\mathrm{Mo}(\mathrm{VI})$. The content of elements in the spent catalyst was determined using XRF analysis (Malvern PANalytical Epsilon 1, Malvern, United Kingdom).

Standard deviations calculated for four repetitions of each step of the process did not exceed $5 \%$ for leaching, $8 \%$ for precipitation and extraction, and $8.5 \%$ for stripping.

\section{Conclusions}

Studies on the recovery of Co(II) from the leaching solutions prove that the proposed four-step hydrometallurgical process involving leaching of metals, precipitation of metal hydroxides, $\mathrm{Co}$ (II) extraction with bis(2,4,4-trimethylpentyl)phosphinic acid, and Co(II) stripping from the organic phase can be used to separate cobalt ions from molybdenum from sulfate solutions. During purification of the leaching solution by precipitation of $\mathrm{Al}(\mathrm{III})$ and $\mathrm{Mo}(\mathrm{VI})$ hydroxides, cobalt(II) losses are noted, as $\mathrm{Co}(\mathrm{II})$ 
co-precipitates also as hydroxide or mixed compounds, e.g., $\mathrm{Co}\left(\mathrm{SO}_{4}\right)_{\mathrm{i}}(\mathrm{OH})_{\mathrm{j}} \cdot \mathrm{kH}_{2} \mathrm{O}$ or $\mathrm{CoMoO}_{6} \cdot 0.9 \mathrm{H}_{2} \mathrm{O}$, and passes into the sludge. This phenomenon is unfavorable for further stages of cobalt(II) recovery. Generally, the yield of Co(II) recovery from solution after leaching did not exceed $20 \%$. The yield of $\mathrm{Mo}(\mathrm{VI})$ recovery did not exceed $1 \%$, thus, it is proven that $\mathrm{Co}(\mathrm{II})$ can be effectively separated from $\mathrm{Mo}(\mathrm{VI})$. However, further research should be carried out to increase the total yield of $\mathrm{Co}(\mathrm{II})$ recovery.

Author Contributions: Individual contributions of the authors: conceptualization, resources, K.S. and M.R.-R.; methodology, M.R.-P., M.R.-R., R.C.; formal analysis, visualization, Z.W., M.R.-P., M.R.-R; investigation, Z.W., M.R.-P., R.C.; writing-original draft preparation, review and editing, M.R.-P., K.S., M.R.-R.; supervision, project administration K.S. and M.R.-R. All authors have read and agreed to the published version of the manuscript.

Funding: This research was funded by Ministry of Higher Education and Science, Poland, grant No. 03/32/SBAD/0910.

Acknowledgments: The authors thank one of the Polish waste treatment companies for providing samples of spent industrial catalyst. The authors appreciate the help of Eng. Oliwia Lubiszewska in carrying some leaching experiments.

Conflicts of Interest: The authors declare no conflict of interest.

\section{References}

1. Wieszczycka, K.; Tylkowski, B.; Staszak, K. Metals in Waste, 1st ed.; De Gruyter: Berlin, Germany, 2018.

2. Friedrich, B. Sustainable utilization of metals-processing, recovery and recycling. Metals 2019, 9, 769. [CrossRef]

3. Regel-Rosocka, M. Electronic wastes. Phys. Sci. Rev. 2018, 20180020. [CrossRef]

4. Rzelewska, M.; Regel-Rosocka, M. Wastes generated by automotive industry-Spent automotive catalysts. Phys. Sci. Rev. 2018, 20180021. [CrossRef]

5. Shiju, N.R.; Guliants, V.V. Recent developments in catalysis using nanostructured materials. Appl. Catal. A Gen. 2009, 356, 1-17. [CrossRef]

6. Misono, M. Basis of Heterogeneous Catalysis. In Studies in Surface Science and Catalysis; Misono, M., Ed.; Elsevier, B.V.: Amsterdam, The Netherland, 2013; Volume 176, pp. 1-23.

7. Cimino, S.; Lisi, L. Catalyst deactivation, poisoning and regeneration. Catalysts 2019, 9, 668. [CrossRef]

8. Marafi, M.; Stanislaus, A. Options and processes for spent catalyst handling and utilization. J. Hazard. Mater. 2003, 101, 123-132. [CrossRef]

9. Chiranjeevi, T.; Pragya, R.; Gupta, S.; Gokak, D.T.; Bhargava, S. Minimization of waste spent catalyst in refineries. Procedia Environ. Sci. 2016, 35, 610-617. [CrossRef]

10. Marafi, M.; Stanislaus, A. Studies on recycling and utilization of spent catalysts: Preparation of active hydrodemetallization catalyst compositions from spent residue hydroprocessing catalysts. Appl. Catal. B Environ. 2007, 71, 199-206. [CrossRef]

11. US EPA. Hazardous waste management system: Identification and listing of hazardous waste-spent catalysts from dual-purpose petroleum hydroprocessing reactors. Fed. Regist. 2002, 67, 30811.

12. Dong, H.; Zhao, J.; Chen, J.; Wu, Y.; Li, B. Recovery of platinum group metals from spent catalysts: A review. Int. J. Miner. Process. 2015, 145, 108-113. [CrossRef]

13. Zhao, Z.; Qiu, Z.; Yang, J.; Lu, S.; Cao, L.; Zhang, W.; Xu, Y. Recovery of rare earth elements from spent fluid catalytic cracking catalysts using leaching and solvent extraction techniques. Hydrometallurgy 2017, 167, 183-188. [CrossRef]

14. Rivas-Castillo, A.M.; Monges-Rojas, T.L.; Rojas-Avelizapa, N.G. Specificity of Mo and V removal from a spent catalyst by Cupriavidus metallidurans CH34. Waste Biomass Valor. 2019, 10, 1037-1042. [CrossRef]

15. Peng, Z.; Li, Z.; Lin, X.; Tang, H.; Ye, L.; Ma, Y.; Rao, M.; Zhang, Y.; Li, G.; Jiang, T. Pyrometallurgical recovery of platinum group metals from spent catalysts. JOM 2017, 69, 1553-1562. [CrossRef]

16. Dingm, Y.; Zheng, H.; Li, J.; Zhang, S.; Liu, B.; Ekberg, C.; Jian, Z. Recovery of platinum from spent petroleum catalysts: Optimization using response surface methodology. Metals 2019, 9, 354. [CrossRef]

17. Wu, W.C.; Tsai, T.Y.; Shen, Y.H. Tungsten recovery from spent SCR catalyst using alkaline leaching and ion exchange. Minerals 2016, 6, 107. [CrossRef] 
18. Imam, D.M.; El-Nadi, Y.A. Recovery of molybdenum from alkaline leach solution of spent hydrotreating catalyst by solvent extraction using methyl tricaprylammonium hydroxide. Hydrometallurgy 2018, 180, 172-179. [CrossRef]

19. Das, S.; Deshavath, N.N.; Goud, V.V.; Dasu, V.V. Bioleaching of Al from spent fluid catalytic cracking catalyst using Aspergillus species. Biotechnol. Rep. 2019, 23, e00349. [CrossRef]

20. Available online: www.moxba.com (accessed on 4 November 2019).

21. Available online: www.nickelhuette-aue.de (accessed on 4 November 2019).

22. Welkom Bij Sadaci. Available online: www.sadaci.be (accessed on 4 November 2019).

23. Staszak, K. Chemical and petrochemical industry. Phys. Sci. Rev. 2018, 4. [CrossRef]

24. Akcil, A.; Vegliò, F.; Ferella, F.; Okudan, M.D.; Tuncuk, A. A review of metal recovery from spent petroleum catalysts and ash. Waste Manag. 2015, 45, 420-433. [CrossRef]

25. Saguru, C.; Ndlovu, S.; Moropeng, D. A review of recent studies into hydrometallurgical methods for recovering PGMs from used catalytic converters. Hydrometallurgy 2018, 182, 44-56. [CrossRef]

26. Moosakazemi, F.; Mohammadi, M.R.T.; Zakeri, M.; Esmaeili, M.J.; Rafiei, H. Development of an environmentally friendly flowsheet for the hydrometallurgical recovery of nickel and aluminum from spent methanation catalyst. J. Clean. Prod. 2020, 244, 18731. [CrossRef]

27. Mouna, H.M.; Baral, S.S. A bio-hydrometallurgical approach towards leaching of lanthanum from the spent fluid catalytic cracking catalyst using Aspergillus niger. Hydrometallurgy 2019, 184, 175-182. [CrossRef]

28. Hamza, M.F.; Roux, J.C.; Guibal, E. Metal valorization from the waste produced in the manufacturing of Co/Mo catalysts: Leaching and selective precipitation. J. Mater. Cycles Waste Manag. 2019, 21, 525-538. [CrossRef]

29. Lai, Y.C.; Lee, W.J.; Huang, K.L.; Wu, C.M. Metal recovery from spent hydrodesulfurization catalysts using a combined acid-leaching and electrolysis process. J. Hazard. Mater. 2008, 154, 588-594. [CrossRef]

30. Barik, S.P.; Park, K.H.; Parhi, P.K.; Park, J.T.; Nam, C.W. Extraction of metal values from waste spent petroleum catalyst using acidic solutions. Sep. Purif. Technol. 2012, 101, 85-90. [CrossRef]

31. Maljković, D.; Lenhard, Z.; Balen, M. Extraction of Co(II) and Ni(II) with Cyanex 272. In EMC 91: Non-Ferrous Metallurgy_Present and Future; Springer: Dordrecht, The Netherlands, 1991.

32. Valverde, I.M., Jr.; Paulino, J.F.; Afonso, J.C. Hydrometallurgical route to recover molybdenum, nickel, cobalt and aluminum from spent hydrotreating catalysts in sulphuric acid medium. J. Hazard. Mater. 2008, 160, 310-317. [CrossRef]

33. Miazga, B.; Mulak, W. Leaching of nickel from spent catalysts in hydrochloric acid solutions. Physicochem. Probl. Miner. Process. 2008, 42, 177-184.

34. Huang, J.H.; Kargl-Simard, C.; Oliazadeh, M.; Alfantazi, A.M. pH-Controlled precipitation of cobalt and molybdenum from industrial waste effluents of a cobalt electrodeposition process. Hydrometallurgy 2004, 75, 77-90. [CrossRef]

35. Bhattacharya, I.N.; Gochhayat, P.K.; Mukherjee, P.S.; Paul, S.; Mitra, P.K. Thermal decomposition of precipitated low bulk density basic aluminium sulfate. Mater. Chem. Phys. 2004, 88, 32-40. [CrossRef]

36. Nguyen, T.H.; Lee, M.S. Development of a hydrometallurgical process for the recovery of calcium molybdate and cobalt oxalate powders from spent hydrodesulphurization (HDS) catalyst. J. Clean. Prod. 2015, 90, 388-396. [CrossRef]

37. Banda, R.; Sohn, S.H.; Lee, M.S. Process development for the separation and recovery of Mo and Co from chloride leach liquors of petroleum refining catalyst by solvent extraction. J. Hazard. Mater. 2012, 213-214, 1-6. [CrossRef] [PubMed]

38. Janiszewska, M.; Markiewicz, A.; Regel-Rosocka, M. Hydrometallurgical separation of Co(II) from Ni(II) from model and real waste solutions. J. Clean. Prod. 2019, 228, 746-754. [CrossRef]

39. Regel-Rosocka, M.; Staszak, K.; Wieszczycka, K.; Masalska, A. Removal of cobalt(II) and zinc(II) from sulphate solutions by means of extraction with sodium bis(2,4,4-trimethylpentyl)phosphinate (Na-Cyanex 272). Clean Technol. Environ. Policy 2016, 18, 1961-1970. [CrossRef]

40. Zhu, Z.; Pranolo, Y.; Zhang, W.; Cheng, C.Y. Separation of cobalt and zinc from concentrated nickel sulfate solutions with Cyanex 272. J. Chem. Technol. Biotechnol. 2011, 86, 75-81. [CrossRef] 
41. CYANEX ${ }^{\circledR} 272$ Extractant; Brochure of Cytec Industries Inc. 2008. Available online: http://www.annualreports. com/HostedData/AnnualReportArchive/c/NYSE_CYT_2008.pdf (accessed on 20 December 2019).

42. Chauhan, G.; Pant, K.K.; Nigam, K.D.P. Metal recovery from hydroprocessing spent catalyst: A green chemical engineering approach. Ind. Eng. Chem. Res. 2013, 52, 16724-16736. [CrossRef]

(C) 2020 by the authors. Licensee MDPI, Basel, Switzerland. This article is an open access article distributed under the terms and conditions of the Creative Commons Attribution (CC BY) license (http://creativecommons.org/licenses/by/4.0/). 